\title{
ИМПЛЕМЕНТАЦИЯ ПРАВОВЫХ ПОЗИЦИЙ ЕВРОПЕЙСКОГО СУДА ПО ПРАВАМ ЧЕЛОВЕКА ВЫСШИМ АРБИТРАЖНЫМ СУДОМ РОССИЙСКОЙ ФЕДЕРАЦИИ И ПРОЦЕСС КОНСТИТУЦИОНАЛИЗАЦИИ ПРАВОСУДИЯ
}

\author{
А. Г. Кузьмин \\ Южно-Уральский государственный университет, г. Челябинск
}

\begin{abstract}
В статье рассматривается роль прекратившего деятельность ВАС РФ в имплементации правовых позиций Европейского Суда по правам человека. Обосновывается тезис о том, что, транслируя практику ЕСПЧ и формулируя на основе либо с учетом его правовых позиций собственные судебно-правовые позиции, ВАС РФ осуществлял достаточно активное участие в конституционализации права, которое выражалось в совершенствовании конституционно-правовой модели судопроизводства, обеспечении ее соответствия актуальным социальным потребностям с учетом международно-правовых стандартов, критериев и практики. Кроме того, судебноправовые позиции ВАС РФ, основанные на прецедентном значении практики ЕСПЧ, могут рассматриваться в качестве юридического инструментария устранения неясности нормы закона, ее противоречивости или иного дефекта. Отмечается необходимость последовательного учета в судебной практике выработанных Конституционным Судом РФ подходов и требований к разрешению возможных коллизий между правовыми позициями ЕСПЧ и оценками конституционности положений российского законодательства.

Ключевые слова: судебно-правовые позиции, судебная система, Высший Арбитражный Суд РФ, судебное решение, правовые позиции ЕСПЧ, конституционализация правосудия.
\end{abstract}

Общепризнано, что, являясь частью европейского правового пространства, Россия не может дистанцироваться от процесса сближения национальных и международных (в том числе региональных) стандартов защиты субъективных прав, в том числе и в сфере отправления правосудия. В данном контексте представляется актуальным исследование соотношения правовых позиций Европейского Суда по правам человека (далее - Европейский Суд, ЕСПЧ) и судебно-правовых позиций действовавшего Высшего Арбитражного Суда РФ в процессе конституционализации правосудия.

Дискуссия о степени обязательности для Российской Федерации правовых позиций, сформулированных в постановлениях Европейского Суда, на протяжении длительного времени была достаточно острой, в том числе, в связи с отрицанием многими юристами «прецедентного права» и, как следствие, облигатного характера постановлений ЕСПЧ для России. В правовой доктрине отстаивалась и точка зрения, согласно которой в на- циональном праве применимы лишь те правовые позиции Европейского Суда, которые выражены в решениях ЕСПЧ против России. Единый подход к указанному вопросу отсутствовал и в судебной практике, о чем свидетельствует отказ некоторых судов применять постановления ЕСПЧ на том основании, что в соответствии с положениями ГК РФ они не имеют преюдициального значения. Это обстоятельство в свою очередь служило основанием для обращения ряда заявителей в Конституционный Суд РФ, который при обосновании своих решений ссылался на практику Европейского Суда, не ограничиваясь при этом исключительно делами ЕСПЧ против России.

Полагаем, что интерпретационная и правоустанавливающая практика Конституционного Суда РФ обеспечила поэтапное разрешение всех обозначенных выше разночтений. В Постановлении от 5 февраля 2007 г. № 2-П «По делу о проверке конституционности положений статей $16,20,112,336,376,377,380$, 381, 382, 383, 387, 388 и 389 Гражданского 


\section{Проблемы и вопросы конституционного и административного права}

процессуального кодекса Российской Федерации в связи с запросом Кабинета Министров Республики Татарстан, жалобами открытых акционерных обществ «Нижнекамскнефтехим» и «Хакасэнерго», а также жалобами ряда граждан» высший орган конституционной юстиции указал, что в силу ч. 4 ст. 15 Конституции РФ общепризнанные принципы и нормы международного права и международные договоры Российской Федерации являются составной частью ее правовой системы, причем международный договор Российской Федерации имеет приоритет перед законом при наличии коллизии между ними. При ратификации Конвенции о защите прав человека и основных свобод (далее - Конвенция) юрисдикция ЕСПЧ была признана Россией обязательной по вопросам толкования и применения указанной конвенции и Протоколов к ней в случаях предполагаемого нарушения Российской Федерацией их положений. Таким образом, решения Европейского Суда, как и Конвенция, в той части, в какой ими, исходя из общепризнанных принципов и норм международного права, дается толкование содержания закрепленных в Конвенции прав и свобод, являются составной частью российской правовой системы, а потому должны учитываться федеральным законодателем при регулировании общественных отношений и правоприменительными органами при применении соответствующих норм права.

На наш взгляд, формулируя данную правовую позицию, Конституционный Суд РФ неслучайно использует выражение «должны учитываться». При этом нельзя не согласиться с В.Д. Зорькиным в том, что, осуществляя правотворчество и правоприменение, необходимо учитывать и стремиться к сохранению тех сохранившихся «в российской социальной ткани» неписаных норм «здоровой массовой социальной регулятивности», которые в той или иной степени восполняют недостаточную эффективность правового регулирования. Также восприятие и сопряженная с ним ответственность, как пишет ученый, «требуют внимательной оценки рекомендуемых нам для имплементации зарубежных или международных норм, а также решений международных судов, включая их соотнесение с Конституцией России. Здесь требуется решать один очень непростой вопрос: не внесут ли рекомендуемые нормы и решения в наше общество, и без того не вполне доверяющее право- вым институтам, дополнительную толику недоверия к справедливости создаваемых и применяемых законов?» [1, с. 152-153]. Тем самым процессы правотворчества и правоприменения должны перманентно соотноситься с конституционным смыслом их модернизации, одновременно не отрицая возможности рецепции тех «формул» (включая правовые позиции ЕСПЧ), которые выработаны международной практикой.

В литературе нет единства мнений по вопросу о том, насколько универсальный характер носят правовые позиции ЕСПЧ для российской правоприменительной практики и как они соотносятся с правовыми позициями Конституционного Суда РФ и судебноправовыми позициями высших судов, в частности Высшего Арбитражного Суда РФ.

Определенное установление ориентиров для арбитражных судов было заложено в информационном письме ВАС РФ от 20 декабря 1999 г. № C1-7/СМП-1341 «Об основных положениях, применяемых Европейским Судом по правам человека при защите имущественных прав и права на правосудие», отражающем тенденции доктринального толкования правовых позиций ЕСПЧ по различным категориям рассматриваемых им дел. Однако, информационное письмо завершалось фразой: «...прошу принять во внимание изложенные положения при осуществлении правосудия в арбитражных судах Российской Федерации», что не позволяло однозначно установить степень обязательности прецедентной практики ЕСПЧ для арбитражных судов, начиная с ВАС РФ.

Существенную роль в выработке единообразных подходов к их решению сыграли постановления Пленума Верховного Суда РФ, включая его Постановление от 27 июня 2013 г. № 21 «О применении судами общей юрисдикции Конвенции о защите прав человека и основных свобод от 4 ноября 1950 года и Протоколов к ней». В частности, согласно данному Постановлению: 1) правовые позиции ЕСПЧ, которые содержатся в окончательных постановлениях Суда, принятых в отношении Российской Федерации, являются обязательными для судов; 2) с целью эффективной защиты прав и свобод человека судами учитываются правовые позиции Европейского Суда, изложенные в ставших окончательными постановлениях, которые приняты в отношении других государств - участников 
Конвенции; при этом правовая позиция учитывается судом, если обстоятельства рассматриваемого им дела являются аналогичными обстоятельствам, ставшим предметом анализа и выводов ЕСПЧ; 3) содержание прав и свобод, предусмотренных законодательством Российской Федерации, должно определяться судами с учетом содержания аналогичных прав и свобод, раскрываемого Европейским Судом при применении Конвенции и Протоколов к ней; 4) во избежание нарушения прав и свобод человека, в том числе необоснованного их ограничения, правовые позиции ЕСПЧ учитываются при применении не только Конвенции и Протоколов к ней, но и иных международных договоров Российской Федерации.

При этом исполнение решений ЕСПЧ в широком его понимании предполагает процесс масштабной имплементации стандартов Конвенции в ее толковании Европейским Судом в повседневную правоприменительную практику; в более узком смысле - принятие как мер общего характера (направленных на профилактику и недопущение в будущем нарушений, подобных установленному), так и индивидуальных, целью которых является восстановление нарушенных прав данного конкретного заявителя.

В целом указанный подход, на наш взгляд, вполне разделялся ВАС РФ на всех этапах его деятельности, применительно к разнообразным конкретным обстоятельствам, что получало отражение в формулировании судебно-правовых позиций, выраженных в постановлениях Пленума и Президиума ВАС РФ.

По нашему мнению, обращение ВАС РФ к нормативным положениям Конвенции и их толкованию в прецедентной практике Европейского Суда активно способствовало конституционализации правосудия, утверждая необходимость применения на практике европейских стандартов его отправления.
Резюмируя сказанное, можно утверждать, что на протяжении своей деятельности, «транслируя» в правовую систему России практику ЕСПЧ и формулируя на основе либо с учетом его правовых позиций собственные судебно-правовые позиции, ВАС РФ содействовал совершенствованию гражданского и административного судопроизводств, приближению российской арбитражной судебной практики к международно-правовым стандартам. Судебно-правовые позиции ВАС РФ, основанные на прецедентном значении практики ЕСПЧ, могут рассматриваться арбитражной практикой в качестве особого юридического инструментария устранения неясности нормы закона, ее противоречивости или иного дефекта. В частности, фактический (ситуационный) приоритет принципа беспристрастности судебного разбирательства, как одной из основных гарантий права на справедливую судебную защиту, перед принципом свободы договора (в его процессуальном измерении) был установлен ВАС РФ именно под влиянием практики и правовых позиций ЕСПЧ. Вместе с тем в современной ситуации арбитражные суды всех уровней, а равно и Верховный Суд РФ, должны последовательно учитывать выработанные Конституционным Судом РФ, в частности в Постановлении от 6 декабря 2013 г. № 27-П «По делу о проверке конституционности положений статьи 11 и пунктов 3 и 4 части четвертой статьи 392 Гражданского процессуального кодекса Российской Федерации в связи с запросом президиума Ленинградского окружного военного суда», подходы и требования к разрешению возможных коллизий между правовыми позициями и оценками конституционности положений российского законодательства, Конституционного Суда РФ и ЕСПЧ.

\section{Литература}

1. Зорькин, В. Д. Правовой путь России / В. Д. Зорькин. - М., 2014. - 192 с.

Кузьмин Андрей Георгиевич - кандидат юридических наук, доцент, профессор кафедры конституционного и административного права, Южно-Уральский государственный университет, г. Челябинск. E-mail: akuzmin@chelarbitr.ru.

Статья поступила в редакцию 28 сентября 2015 2. 
DOI: $10.14529 /$ law150415

\title{
THE IMPLEMENTATION OF LEGAL POSITIONS OF THE EUROPEAN COURT OF HUMAN RIGHTS BY THE SUPREME ARBITRATION COURT OF THE RUSSIAN FEDERATION AND THE PROCESS OF CONSTITUTIONALIZATION OF JUSTICE
}

\author{
A. G. Kuzmin \\ South Ural State University, Chelyabinsk, Russian Federation
}

The article considers the role of the SAC, which ceased operations in the implementation of legal positions of the European Court of Human Rights. The author proves the thesis that by broadcasting the practice of the ECHR and formulating on the basis of either its legal position of their own judicial and legal position, the SAC was actively involved in the constitutionalization of law, which was expressed in the improvement of the constitutional and legal model of judicial procedure, ensuring its compliance with the relevant social needs, taking into account the international legal standards, criteria and practices. Moreover, the judicial and legal positions of the SAC, based on the precedential value of the ECHR, can be considered as a legal tool to eliminate the ambiguity of rules of law, its contradictions, or other defect. The author notes the need to take into account in the court practice the developed by the Constitutional Court of the Russian Federation approaches and requirements to resolve potential conflicts between the legal positions of the ECHR and the estimates of the constitutionality of the provisions of the Russian legislation.

Keywords: judicial and legal positions, judicial system, Supreme Arbitration Court of the Russian Federation, court holding, legal positions of the ECHR, constitutionalization of justice.

\section{References \\ 1. Zor'kin V. D. Pravovoy put' Rossii [The legal way to Russia]. Moscow, 2014, 192 p.}

Andrey Georgievich Kuzmin - Candidate of Science (Law), Associate Professor, Professor of Constitutional and Administrative Law Department, South Ural State University, Chelyabinsk, Russian Federation. E-mail: akuzmin@chelarbitr.ru.

Received 28 September 2015.

\section{ОБРАЗЕЦ ЦИТИРОВАНИЯ}

Кузьмин, А. Г. Имплементация правовых позиций Европейского Суда по правам человека Высшим Арбитражным Судом Российской Федерации и процесс конституционализации правосудия / А. Г. Кузьмин // Вестник ЮУрГУ. Серия «Право». - 2015. - Т. 15, № 4. - C. 95-98. DOI: 10.14529/law150415

\section{FOR CITATION}

Kuzmin A. G. The implementation of legal positions of the european court of human rights by the supreme arbitration court of the russian federation and the process of constitutionalization of justice. Bulletin of the South Ural State University. Ser. Law, 2015, vol. 15, no. 4, pp. 95-98. (in Russ.) DOI: 10.14529/law150415 